\title{
512 測距センサを用いた大根積み込み装置の自動化の研究 \\ Study for Automation of the Loading Device for the Japanese White Radish using the Distance Measuring sensor.
}

\author{
○学 野呂田 龍之介(旭川高専) \\ 正 大柏 哲治(旭川高専) \\ 石井 誠士(石井鉄工場)
}

Ryunosuke NOROTA, National Institute of Technology, Asahikawa College

Tetsuji OKASHIWA, National Institute of Technology, Asahikawa College

Seiji ISHII, Ishii Iron Works

Key Words: Automation, Loading Device, The Japanese white radish, The distance measuring sensor

1. 緒言

北海道河西郡芽室町で使用することを目的として開発さ れた大根収穫機には, 収穫した大根を収穫機後部のコンテナ に積み込む装置(Fig.1)がある。この装置は 6 本の油圧シリ ンダによって駆動しており, それぞれをレバー操作により手 動で操作しているが, 作業者の負担が大きいことから教示・ 再生による自動制御を小型モデルを用いて検討してきた。

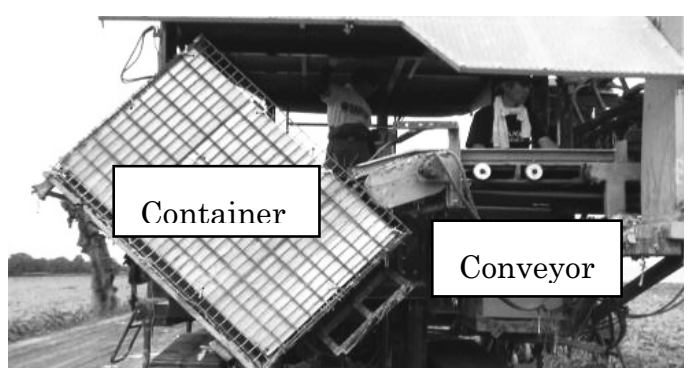

Fig. 1 : The Loading device for radishes

木本らの報告(1)によれば，コンテナ内の大根の積み込み 状況を検出するために光電センサを使用していたが大根に 土が付着していると検出することができないことが分かり， 新たにPSD 測距センサを用いることが提案された。室内で 実験を行った結果, 土等も検出すること, 測定物との距離に 応じた電圧を出力することから, 光電センサよりも優れてい ることが判明した。

しかし実際に使用する屋外において PSD 測距センサが測 定物からの距離に応じた電圧を出力できるかは確かめてい ない，そこで，本研究では屋外で, PSD 測距センサによる 電圧検出実験を行った。

\section{2. 概要}

\subsection{PSD 測距センサ}

PSD 測距センサ(Fig.2)は発光部に赤外発光ダイオード, 受光部に PSD 素子(Position Sensitive Detector)を使用し, 三角測量の原理を利用した光学式の測距センサである.物体
に反射した赤外光が受光素子のどこに入射したかにより電 圧が変化し，その電圧から距離を算出する。以降，PSD 測 距センサは測距センサと略す.

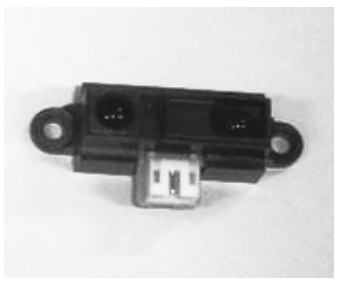

Fig. 2 : PSD distance measuring sensor

\section{2 検出装置の構成}

検出装置の構成とプログラムの処理を Fig.3 のブロック 図に示す.

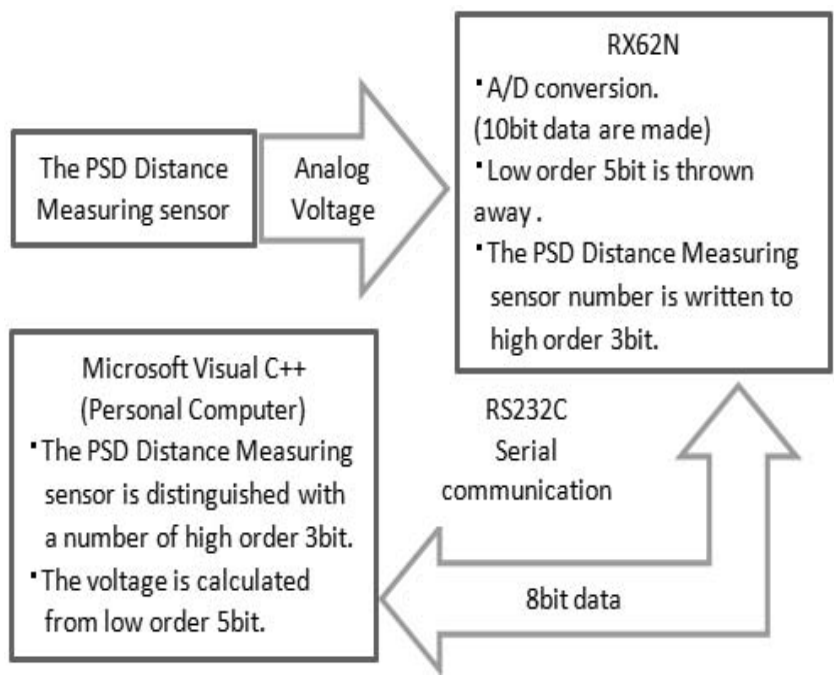

Fig. 3 : Block diagram

$\mathrm{A} / \mathrm{D}$ 変換には，ルネサスエレクトロニクス製 RX62N マ イコンを使用した.

HEW(High-performance Embedded Workshop)という 専用の開発環境を用いて, $\mathrm{C}$ 言語を用いたプログラミングを 行い， $\mathrm{A} / \mathrm{D}$ 変換を行った.

$\mathrm{A} / \mathrm{D}$ 変換で得られるデータは $0 \sim 3.3 \mathrm{~V}$ の電圧データであ 
り，ノイズなどの影響を受けやすい. そこでノイズ対策のた めにシリアル通信 $\mathrm{RS} 232 \mathrm{C}$ を用いた. また, $\mathrm{A} / \mathrm{D}$ 変換で得 られる 10bitのデータをシリアル通信の 1 バイト送信で送る ために，上位 5bit の夕使用することにした。下位 5bit はノ イズの影響を受けやすく，頻繁に変化し，上位 5bit を用い ても電圧分解能が約 $0.1 \mathrm{~V}$ なので実用上問題ないと判断した.

\section{3.実験}

\section{1 概要}

測距センサが屋外で測定物との距離に応じた電圧の出力 を行えるかを確かめる実験を行った. 実験方法は, 測定物と して乾燥した土, 泥, 黒フェルト, 白紙, 大根の 5 種類を 用意し，直射日光下において，センサと測定物を $80 \mathrm{~cm}$ から $10 \mathrm{~cm}$ まで $5 \mathrm{~cm}$ ずつ近づけながら電圧と照度を記録した. 実験は同様の方法で 3 回ずつ行った。また，白紙および大 根については日かげでも同様の実験を行った。

\section{2 結果}

ここでは, 泥と大根の結果を示す. Fig.4 は泥の, Fig.5 は大根の直射日光下(照度 90000〜 70000Lux)の実験結果で ある。

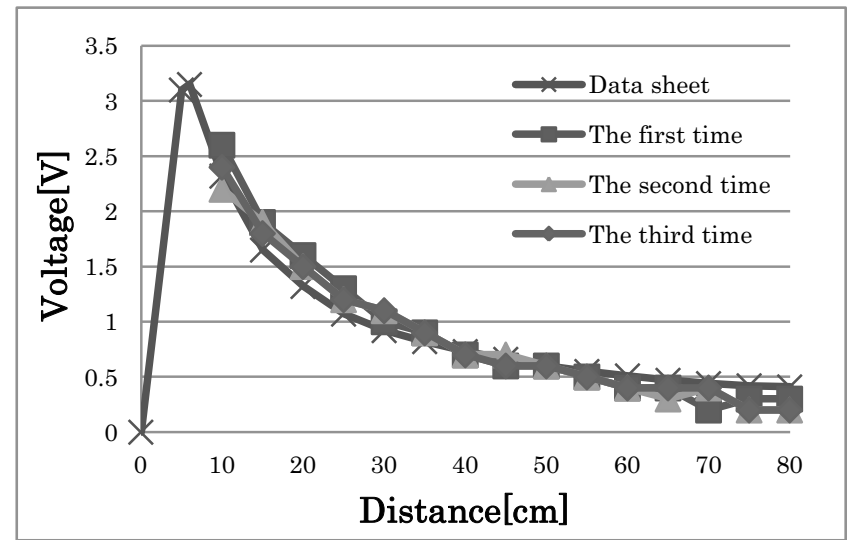

Fig. 4 : The result of the mud. (in direct sunlight)

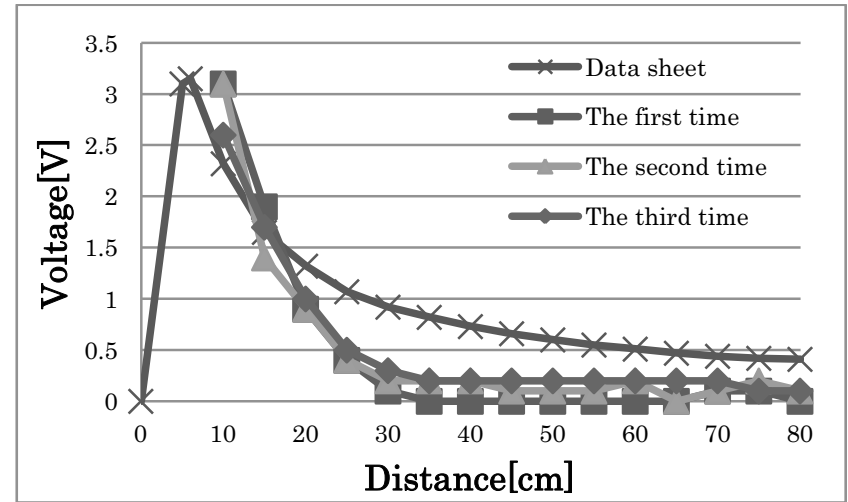

Fig. 5 : The result of the Japanese white radish. (in direct sunlight)

泥は，おおよそデータシート(2)の電圧值と一致すること
が分かった。しかし, 大根はセンサとの距離が遠い時には, 電圧值がデータシートよりも低くなりほぼ横ばいに変化す ること，近い時には高くなることが分かった，そこで，大根 については日かげ(照度 15000〜 7000Lux)での実験も行っ た. Fig.6はその実験結果である.

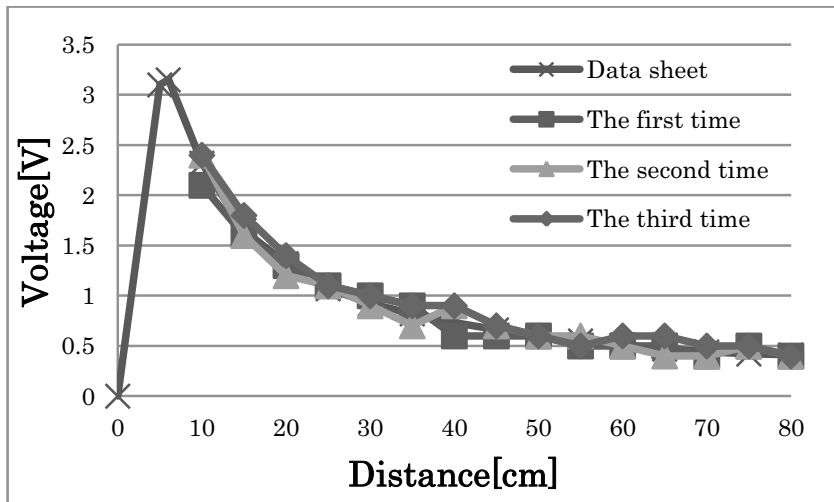

Fig. 6 : The result of the Japanese white radish. (in the shade)

おおよそデータシートの電圧值と一致している.

したがって，日かげでは大根も測定できることが分かった． なお，乾燥した土，黒フェルトは泥と同様の傾向を，白紙 は日光下でも日かげでも大根と同様の傾向を示した。

以上の結果から, 日かげであればどの測定物でもデータシ ート同様の結果が得られることが分かった．したがって, 実 際の積み込み装置での利用にはコンテナの中に直射日光が 当たらない工夫をする必要がある.

\section{4.結言}

今回の研究により, 測距センサは屋外の作業においても日 かげであれば使用できることが分かった。しかし，実際に使 用するには，コンテナ内に直射日光が当たらない工夫, 測距 センサの距離の情報を活用した効率的な積み込み作業がで きるシステムの構築, 実際の現場で発生する振動やノイズへ の対策, 積み込み作業時にセンサに泥や大根の葉が付着する ことへの対応など検討すべき課題が残っている.今後これら の課題を解決し, 自動化の実現のために, よりよい検出シス テムの構築をめざす。

\section{参考文献}

（1)木本，大柏：大根積込み装置の自動化に関する研究, 北 海道学生会第 43 回学生員卒業研究発表講演会講演論文集 No.606 P.241-242(2014.03.08)

(2)http://www.sharpsma.com/download/GP2Y0A21YK-D ATA-SHEETPDF : GP2Y0A21YK Data Sheet.fm - GP2Y 0A21YK-DATA-SHEETPDF P.4 